\title{
Article \\ Effects of Biogenic ZnO Nanoparticles on Growth, Physiological, Biochemical Traits and Antioxidants on Olive Tree In Vitro
}

\author{
Luca Regni ${ }^{*}+\mathbb{D}$, Daniele Del Buono ${ }^{*}+\mathbb{D}$, Maurizio Micheli ${ }^{*}+\mathbb{D}$, Simona Lucia Facchin, Ciro Tolisano \\ and Primo Proietti (D)
}

check for

updates

Citation: Regni, L.; Del Buono, D.;

Micheli, M.; Facchin, S.L.; Tolisano,

C.; Proietti, P. Effects of Biogenic ZnO

Nanoparticles on Growth,

Physiological, Biochemical Traits and Antioxidants on Olive Tree In Vitro.

Horticulturae 2022, 8, 161. https://

doi.org/10.3390/horticulturae8020161

Academic Editor: Cristina

Moniz Oliveira

Received: 22 January 2022

Accepted: 9 February 2022

Published: 12 February 2022

Publisher's Note: MDPI stays neutral with regard to jurisdictional claims in published maps and institutional affiliations.

Copyright: (C) 2022 by the authors. Licensee MDPI, Basel, Switzerland. This article is an open access article distributed under the terms and conditions of the Creative Commons Attribution (CC BY) license (https:// creativecommons.org/licenses/by/ $4.0 /)$.
Department of Agricultural, Food and Environmental Sciences, University of Perugia, Borgo XX Giugno 06121 Perugia, Italy; simona.facchin@studenti.unipg.it (S.L.F.); ciro.tolisano@studenti.unipg.it (C.T.); primo.proietti@unipg.it (P.P.)

* Correspondence: luca.regni@unipg.it (L.R.); daniele.delbuono@unipg.it (D.D.B.); maurizio.micheli@unipg.it (M.M.)

† These authors contribute equally to the work.

\begin{abstract}
Currently, there is an increasing interest in nanotechnology, since some nanomaterials can enhance crop growth, yield, nutritional status, and antioxidant defences. This work aimed to investigate for the first time the influence of zinc oxide nanoparticles ( $\mathrm{ZnO}-\mathrm{NPs}$ ) on the in vitro growth and biochemical parameters of the olive tree (cv. Moraiolo). With this goal, biogenic ZnO-NPs (spherical shape and dimensions in the range of 10-20 nm), deriving from a green synthesis carried out with a Lemna minor L. extract were used. Different concentrations $\left(0,2,6\right.$ and $\left.18 \mathrm{mg} \mathrm{L}^{-1}\right)$ of ZnO-NPs were added to the olive growth medium (OM substrate), and three sub-cultures of 45 days each were carried out. ZnO-NPs at 6 and $18 \mathrm{mg} \mathrm{L}^{-1}$ enhanced some growth parameters in the olive tree explants, such as the number of shoots, green fresh and total dry weight. Moreover, the abovementioned concentrations raised the chlorophyll $\mathrm{a}$ and $\mathrm{b}$ content and soluble protein. Finally, concerning the dosage applied, the treatments stimulated the content of carotenoids, anthocyanins, total phenol content (TPC), and the radical scavenging activity towards DPPH (2.2-diphenyl-1-picrylhydrazyl). In conclusion, this study highlighted that biogenic $\mathrm{ZnO}$-NPs exerted beneficial effects on the olive tree explants in vitro, improving the effectiveness of the micropropagation technique.
\end{abstract}

Keywords: Olea europaea L.; Lemna minor L.; micropropagation; zinc; nanoparticles; biostimulatory action; plant performance; antioxidant activity

\section{Introduction}

Zinc $(\mathrm{Zn})$ is an essential micronutrient involved in many biological processes which take place in plants, being a cofactor of numerous enzymes such as RNA polymerase, superoxide dismutase, alcohol dehydrogenase, and carbonic anhydrase. For this reason, $\mathrm{Zn}$ is essential for protein, carbohydrates and lipids synthesis and nucleic acids and antioxidant metabolism [1]. Moreover, Zn contributes to cell proliferation and differentiation [2], plays a vital role in chloroplast development, and regulates some of its functions, such as the repair process of the photosystem II when damaged by light radiation [3]. Zn deficiency in plants causes the inhibition of photosynthesis [1], stunted growth, chlorosis, and spikelet sterility in the Poaceae family [4]. On the contrary, excessive amounts of zinc can be toxic to plants because, in ionic form, this element can compete with other cations for the same binding sites [1]. Some of the symptoms related to $\mathrm{Zn}$ excess are reductions of plant biomass, chlorosis of young leaves, and the inhibition of root growth [5]. For these reasons, $\mathrm{Zn}$ is considered an essential nutrient for plant growth and development, even if it could be toxic in excessive amounts.

The utilization of nanotechnology is a promising tool not only for the industrial and medical sectors but also for agriculture, as some nanomaterials can prompt beneficial 
effects in crops by improving their growth, yield, nutritional status, and antioxidant defences $[1,6,7]$. The term nanoparticles (NPs) generally refers to materials exhibiting particle sizes below $100 \mathrm{~nm}$ in at least one dimension [8]. NPs are traditionally obtained by physical and chemical methods, which can be costly and require toxic chemicals and harsh conditions [9]. These aspects represent the main inconvenience of the NPs production since they can create potential threats to human health and the environment.

Despite this, the need to obtain NPs in an environmentally friendly way, i.e., by lowering the impact of the traditional synthetic techniques, has led to exploring and setting new strategies for synthesizing them [7]. For this purpose, the use of plant extracts to carry out the NPs synthesis is proving successful and therefore gaining increasing interest $[10,11]$. Indeed, based on appropriate biological entities, this synthetic approach, generally referred to as biogenic synthesis, can make it possible to synthesize a variety of metal oxide nanoparticles [12]. The case of zinc oxide nanoparticles (ZnO-NPs) is particularly interesting, as $\mathrm{ZnO}-\mathrm{NPs}$ can be efficiently obtained using plant extracts [13,14], and the resulting NPs are considered safer and less toxic than those where other metals are present in the oxides [15].

In line with the above, ZnO-NPs are among the most widely used metal oxide NPs in the agricultural and food sectors [16]. According to the U.S. Food and Drug Administration, $\mathrm{ZnO}$ at micro and nano-size is registered as "generally recognized as safe (GRAS)" material [7]. Different studies have reported both positive and negative effects of ZnO-NPs on the growth of different plant species. In particular, these nanomaterials may have stimulatory effects when supplemented at low concentrations while having inhibitory and phytotoxic effects at high concentrations [17]. For instance, seed priming of Cicer arietinum L. with ZnO-NPs increased the level of IAA in sprouts roots [18]. On the contrary, Lin and Xing observed that $\mathrm{ZnO}-\mathrm{NPs}$ exerted a dose-dependent inhibitory effect on roots elongation, and if subministrated at doses exceeding $20 \mathrm{mg} \mathrm{L}^{-1}$, they decreased seedling biomass production [19].

Therefore, the results of studies on this topic sometimes appear contradictory. This may be due to many factors that can influence the effects of $\mathrm{ZnO}-\mathrm{NPs}$, such as particle size and shape, the stage of plant development, the method and the dose of application, and the duration of exposure [7]. In addition, crop responses to the treatments with ZnO-NPs should be mainly considered as species-dependent. Indeed, up to $1.000 \mathrm{mg} \mathrm{L}^{-1} \mathrm{ZnO}-\mathrm{NPs}$ promoted seed germination and growth in Arachis hypogaea L., while at $2.000 \mathrm{mg} \mathrm{L}^{-1}$ toxic effects were observed [20]. ZnO-NPs at the concentration of $80 \mathrm{mg} \mathrm{L}^{-1}$ caused an increase in plant height, seeds per spike, seed weight, yield, and biomass accumulation in Triticum aestivum L. [21]. On the contrary, negative effects such as increased DNA fragmentation and ROS production were observed by Ghosh et al., 2016 in Allium cepa L. at dosages higher than $200 \mathrm{mg} \mathrm{L}^{-1}$ [22]. In T. aestivum L. at 100 and $200 \mu \mathrm{M}$ ZnO-NPs decreased photosynthetic and antioxidant activities and increased hydrogen peroxide and lipid peroxidation [23].

As for plant in vitro cultivation, some studies revealed positive effects of NPs on seed germination, callus induction, shoot multiplication, and plant growth [16,24-27]. However, as in part already stated, the effect of NPs on plant performance is highly dependent on plant genotype and nanoparticle type, size, and concentration [28].

In spite of this, to the best of our knowledge, no studies have been conducted to date on the effects of ZnO-NPs on olive trees cultivated in vitro. In this context, it is necessary to point out that the micropropagation (which represents an application of in vitro cultures) of rootstocks and cultivars in several tree species, including the olive tree, is increasing worldwide because it has many advantages compared to the traditional propagation systems (cutting and grafting) [29-31]. The main advantages of micropropagation are the high genetic and sanitary quality of the propagated material and the possibility of producing a high number of plants in a small space and short period [32]. Moreover, the opportunity to have plant material with juvenile characters, i.e., able to develop in a short time and, therefore, to provide fast responses to various treatments, is considered very interesting. 
Hence, this work aimed to investigate for the first time the influence of ZnO-NPs on the in vitro growth and biochemical parameters of the olive tree. To this end, this study employed biogenic ZnO-NPs, obtained using an extract of Lemna minor L., whose synthesis, size and morphological characteristics are reported in a very recently published study [7]. In particular, the biogenic ZnO-NPs employed in this study showed a nano-spherical structure with dimensions in the range of 10-20 $\mathrm{nm}$ [7].

\section{Materials and Methods}

\subsection{Growth Conditions of Lemna Minor and Synthesis and Characterization of Biogenic ZnO-NPS}

Complete details about the biogenic synthesis and characterization of ZnO-NPs are reported in the paper published by Del Buono et al. [7].

Lemna minor L. was grown in polyethylene trays containing a nutrient solution consisting of $3.46 \mathrm{mmol} \mathrm{L}^{-1} \mathrm{KNO}_{3}, 1.25 \mathrm{mmol} \mathrm{L}^{-1} \mathrm{Ca}\left(\mathrm{NO}_{3}\right)_{2} \times 4 \mathrm{H}_{2} \mathrm{O}, 0.66 \mathrm{mmol} \mathrm{L}^{-1}$ $\mathrm{KH}_{2} \mathrm{PO}_{4}, 0.071 \mathrm{mmol} \mathrm{L}^{-1} \mathrm{~K}_{2} \mathrm{HPO}_{4}, 0.41 \mathrm{mmol} \mathrm{L}^{-1} \mathrm{MgSO}_{4} \times 7 \mathrm{H}_{2} \mathrm{O}, 0.28 \mathrm{mmol} \mathrm{L}^{-1} \mathrm{~K}_{2} \mathrm{SO}_{4}$, $1.94 \mu \mathrm{mol} \mathrm{L} \mathrm{H}_{3} \mathrm{BO}_{3}, 0.63 \mu \mathrm{mol} \mathrm{L}{ }^{-1} \mathrm{ZnSO}_{4} \times 7 \mathrm{H}_{2} \mathrm{O}, 0.18 \mu \mathrm{mol} \mathrm{L}-1\left(\mathrm{NH}_{4}\right)_{6} \mathrm{Mo}_{7} \mathrm{O}_{24} \times$ $4 \mathrm{H}_{2} \mathrm{O} \times 2 \mathrm{H}_{2} \mathrm{O}, 1 \mu \mathrm{mol} \mathrm{L}{ }^{-1} \mathrm{MnSO}_{4} \times \mathrm{H}_{2} \mathrm{O}, 21.80 \mu \mathrm{mol} \mathrm{L}{ }^{-1}$ FeEDTA, $1 \mu \mathrm{mol} \mathrm{L}{ }^{-1} \mathrm{CuSO}_{4}$. Trays were submitted to $120 \mu \mathrm{mol} \mathrm{m} \mathrm{m}^{-2} \mathrm{~s}^{-1}$ of light intensity (photoperiod: $12 / 12 \mathrm{~h}$-light/dark) at $24 \pm 2{ }^{\circ} \mathrm{C}$. The growth media was renewed every two weeks.

For the biogenic ZnO-NPs synthesis, about $20 \mathrm{~g}$ of fresh plant tissue were harvested, washed and dried. One gram of dried tissue was extracted with $40 \mathrm{~mL}$ of $25 \%$ ethanol-water $(v / v)$, stirred at $80^{\circ} \mathrm{C}$ for $15 \mathrm{~min}$, and filtered to collect the liquid phase (plant extract). $30 \mathrm{~mL}$ of the plant extract was added dropwise to $50 \mathrm{~mL}$ of $1.40 \mathrm{M} \mathrm{ZnSO} 4 \times 7 \mathrm{H}_{2} \mathrm{O}$ and maintained at $80{ }^{\circ} \mathrm{C}$ for $2 \mathrm{~h}$, slowly increasing the $\mathrm{pH}$. The precipitate was recovered by centrifugation, washed, and left for $16 \mathrm{~h}$ in an oven at $80^{\circ} \mathrm{C}$. Finally, the ZnO-NPs were obtained for calcination in a muffle at $400{ }^{\circ} \mathrm{C}$ for $4 \mathrm{~h}$ [7].

The ZnO-NPs were characterized by XRD (X-ray diffraction), FE-SEM (field emission gun electron scanning microscopy), EDX (energy dispersive x-ray spectroscopy), TEM (transmission electron microscope) and UV-vis (ultraviolet-visible spectrophotometry), which evidenced nanoparticles of spherical shape and dimension in the range 10-20 nm [7].

\subsection{Plant Material, $\mathrm{ZnO}-\mathrm{NPs}$ Treatment, and Growing Conditions}

The experiment was conducted on the olive tree cultivar 'Moraiolo'. The initial explants were represented by about $10 \mathrm{~mm}$ long portions with a single node excised from proliferated shoots grown on an olive medium (OM) [33]. The shoots apical portions were not used since it is known that the apical bud is more vigorous due to the apical dominance. Glass vessels ( $500 \mathrm{~mL}$ capacity) were used, each containing ten explants with two leaves and $100 \mathrm{~mL}$ of the OM enriched with sucrose $\left(30 \mathrm{~g} \mathrm{~L}^{-1}\right)$, agar $\left(7 \mathrm{~g} \mathrm{~L}^{-1}\right)$ and zeatin $\left(4 \mathrm{mg} \mathrm{L}^{-1}\right)$, $\mathrm{pH}$ equal to 5.5. The substrates and vessels were autoclaved at $115^{\circ} \mathrm{C}$ for 20 min before being used in aseptic conditions under a horizontal laminar flow cabinet. In particular, the experimental framework involved the evaluation of the effects on shoots proliferation of substrates containing four different concentrations of $\mathrm{ZnO}-\mathrm{NPs}\left(0,2,6\right.$, and $\left.18 \mathrm{mg} \mathrm{L}^{-1}\right)$. The solution containing $\mathrm{ZnO}-\mathrm{NPs}$ was added to the substrate before autoclaving. The cultures were then placed in a growth chamber at $22 \pm 2{ }^{\circ} \mathrm{C}$ of temperature and 16 -h photoperiod with a light intensity of $40 \mu \mathrm{E} \mathrm{m}^{-2} \mathrm{~s}^{-1}$. For each treatment, six vessels (replicates) for each one of the three subsequent subcultures were used. At the end of each subculture (45 days), this was allowed to carry out the destructive measurements on the proliferated shoots of three pots and to use the proliferated shoots of the remaining vessels as initial explants for the subsequent subcultures.

\subsection{Growth Parameters}

The following parameters were monitored in 30 proliferated shoots per treatment to evaluate the effect of $\mathrm{ZnO}-\mathrm{NPs}$ :

viability (\%): incidence of green and viable explants;

shoots (n): average number of shoots developed from each initial explant; 
shoot length ( $\mathrm{mm})$ : average length of developed shoots;

nodes (n): average number of nodes developed by each initial explant, reusable for further proliferation subculture (multiplication rate);

callus (\%): incidence of explants that produced basal callus;

green fresh weight $(\mathrm{mg})$ : average fresh weight per explant of developed vegetative organs (leaves, stems, buds);

callus fresh weight (mg): average fresh weight per explant of callus masses developed at the base of explants;

total dry weight $(\mathrm{mg})$ : average dry weight per explant of the vegetative organs and callus, obtained by keeping the plant material in an oven for three days at $105^{\circ} \mathrm{C}$.

2.4. Determinations on In Vitro Proliferated Shoots of Chlorophylls, Carotenoid, Soluble Protein, Anthocyanins, Total Phenol Content (TPC) and Radical Scavenging Rate (DPPH)

Forty-five days after each subculture, shoot tissues were collected, and the content of chlorophyll a (Chl $a)$, chlorophyll $\mathrm{b}(\mathrm{Chl} b)$ and carotenoids (Car) was analyzed. In detail, $50 \mathrm{mg}$ of proliferated shoots were extracted with $5 \mathrm{~mL}$ acetone/water $(80 \%-v / v)$ in a mortar using a pestle and quartz sand and centrifuged at $5000 \mathrm{rpm}$ for $10 \mathrm{~min}$. The supernatant was collected, and the pellet was extracted twice with $5 \mathrm{~mL}$ of $80 \%$ acetone. Then, $\mathrm{Chl} a, \mathrm{Chl} b$ and Car contents were determined spectrometrically [34]. Moreover, the total chlorophylls concentration and the relative ratio of these pigments were expressed as Tot Chl (Chl $a+\mathrm{Chl} b-\mathrm{Tot} \mathrm{Chl})$ and the ratio $\mathrm{Chl} a / \mathrm{Chl} b$, respectively.

About $50 \mathrm{mg}$ of shoot tissue were homogenized in $5 \mathrm{~mL}$ of $0.1 \mathrm{M}$ Tris- $\mathrm{HCl}$ buffer using a cold mortar and pestle. The extract was centrifuged at $5000 \mathrm{rpm}$ for $15 \mathrm{~min}$ at $4{ }^{\circ} \mathrm{C}$. According to Bradford, the protein content was determined using bovine serum albumin (BSA) as standard [35].

The anthocyanins determination was carried out by extracting $50 \mathrm{mg}$ of the proliferated shoots with $5 \mathrm{~mL}$ of ethanol (95\%). Then, the suspension was centrifuged at $5000 \mathrm{rpm}$ for $20 \mathrm{~min}$, and the anthocyanins content was determined according to a published procedure [36].

$50 \mathrm{mg}$ of fresh tissue was extracted with $5 \mathrm{~mL}$ of methanol and left to stir at room temperature overnight to determine the TPC and DPPH. The suspension was then centrifuged at $5000 \mathrm{rpm}$ for $10 \mathrm{~min}$, and the supernatant was collected for TPC and DPPH determinations. The TPC content was determined by adding $0.5 \mathrm{~mL}$ of the extracts to $7 \mathrm{~mL}$ of distilled water and $0.5 \mathrm{~mL}$ of Folin-Ciocalteu's phenol reagent. After $5 \mathrm{~min}, 2 \mathrm{~mL}$ of $2 \%$ sodium carbonate $(w / v)$ were added to this solution, then left to react for $2 \mathrm{~h}$. The TPC content was determined spectrometrically and referred to as gallic acid equivalent (GAE) $\mathrm{g}^{-1}$ [37].

The radical scavenging rate of the methanolic plant extracts was assessed towards the $\mathrm{DPPH}$. To this end, $0.5 \mathrm{~mL}$ of the methanolic extract was added to $1 \mathrm{~mL}$ of ethanol and $1 \mathrm{~mL}$ of a solution $0.101 \mathrm{mM}$ of DPPH (2.2-diphenyl-1-picrylhydrazyl). The solution was left to react for $10 \mathrm{~min}$ at room temperature. Subsequently, the radical scavenging ability of the extract towards the DPPH was calculated as antioxidant activity spectrometrically according to Sheikhalipour et al. [38].

\subsection{Statistical Analysis}

The trials were organized according to a completely randomized design, with four treatments $\left(0,2,6,18 \mathrm{mg} \mathrm{L}^{-1} \mathrm{ZnO}-\mathrm{NPs}\right)$ and 30 proliferated shoots for each treatment during three subcultures. Collected data were subjected to one-way analysis of variance, (ANOVA) and significant differences were assayed by Duncan's test $(p=0.05)$. The statistical environment R 4.0.5 (released on 31 March 2021) was used to perform the analysis [39]. 


\section{Results}

\subsection{Growth Parameters}

The $\mathrm{ZnO}-\mathrm{NPs}$ treatment increased the number of shoots produced at the dosages of 6 and $18 \mathrm{mg} \mathrm{L}^{-1}$ compared to the control $\left(0 \mathrm{mg} \mathrm{L}^{-1}\right)$, corresponding to $1.53,1.65$, and 1.21, respectively (Figure 1). The ZnO-NPs at the dosages of 6 and $18 \mathrm{mg} \mathrm{L}^{-1}$ positively influenced the green fresh weight, which was higher than the control (175.27, 154.04, and $114.20 \mathrm{mg}$, respectively) (Figure 2). A similar trend as observed for the green fresh weight was also found for the total dry weight (Figure 2).
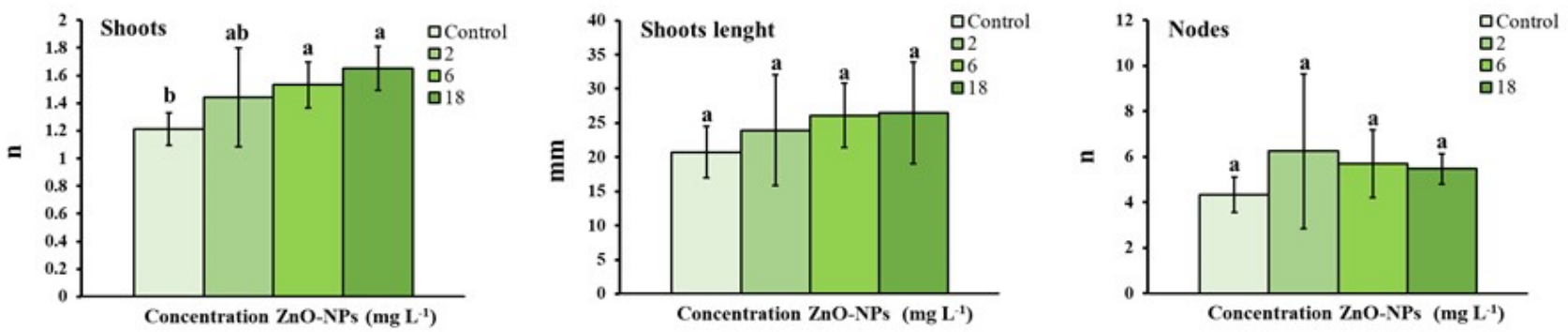

Figure 1. Shoots number, shoots length and, number of nodes values \pm SD of the olive proliferated explants. Means values followed by different letters were significantly different $(p<0.05)$.
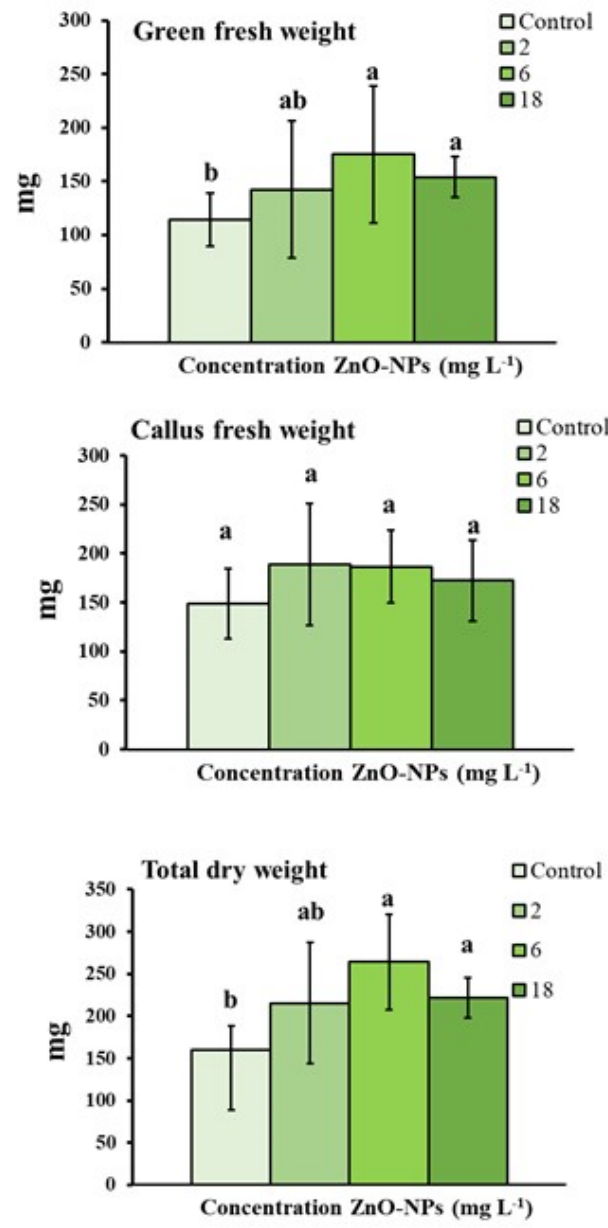

Figure 2. Green fresh and callus weight, total dry weight values $\pm \mathrm{SD}$ of the olive proliferated explants. Means values followed by different letters were significantly different $(p<0.05)$. 
The addition of $\mathrm{ZnO}-\mathrm{NPs}$ to the growth medium did not affect the viability (data not reported), length of shoots and number of nodes (Figure 1) as well as callus fresh weight (Figure 2).

\subsection{Effect of ZnO-NPs on Pigment and Soluble Protein}

Some biochemical aspects of the olive plants treated with the three dosages of ZnO-NPs were studied and the results obtained are reposted in Table 1. In particular, the chlorophyll $\mathrm{a}$ and $\mathrm{b}(\mathrm{Chl} a$ and $\mathrm{Chl} b)$, Tot $\mathrm{Chl}(\mathrm{Chl} a+\mathrm{Chl} b)$, and the soluble protein were investigated, and the outcomes highlighted, in general, some positive effects in response to specific treatments.

Table 1. Chlorophyll a ( $\mathrm{Chl} a)$, chlorophyll b ( $\mathrm{Chl} b$ ), total chlorophyll (Tot $\mathrm{Chl})$, and soluble protein found in olive proliferated explants.

\begin{tabular}{|c|c|c|c|c|}
\hline & $\begin{array}{c}\text { Chl } a \\
\left(\mathrm{mg} \mathrm{g}^{-1} \mathrm{FW}\right)\end{array}$ & $\begin{array}{c}\text { Chl } b \\
\left(\mathrm{mg} \mathrm{g}^{-1} \mathrm{FW}\right)\end{array}$ & $\begin{array}{c}\text { Tot Chl } \\
\left(\mathrm{mg} \mathrm{g}^{-1} \mathrm{FW}\right)\end{array}$ & $\begin{array}{c}\text { Soluble Protein } \\
\left(\mathrm{mg} \mathrm{g}^{-1} \mathrm{FW}\right)\end{array}$ \\
\hline Control & $2.25 \pm 0.22 b$ & $0.76 \pm 0.25 c$ & $3.01 \pm 0.81 c$ & $9.7 \pm 0.4 \mathrm{c}$ \\
\hline $2 \mathrm{mg} \mathrm{L}^{-1}$ & $2.27 \pm 0.27 \mathrm{~b}$ & $0.91 \pm 0.10 \mathrm{bc}$ & $3.18 \pm 0.32 \mathrm{bc}$ & $11.4 \pm 1.2 \mathrm{~b}$ \\
\hline $6 \mathrm{mg} \mathrm{L}^{-1}$ & $2.80 \pm 0.19 a$ & $1.20 \pm 0.13 \mathrm{ab}$ & $4.00 \pm 0.29 \mathrm{ab}$ & $14.2 \pm 0.5 \mathrm{a}$ \\
\hline $18 \mathrm{mg} \mathrm{L}^{-1}$ & $3.13 \pm 0.46 \mathrm{a}$ & $1.30 \pm 0.21 \mathrm{ab}$ & $4.43 \pm 0.70 \mathrm{a}$ & $15.3 \pm 2.0 \mathrm{a}$ \\
\hline
\end{tabular}

Letters in the table, if different, indicate statistically significant differences $(p<0.05)$.

As for Chl $a$, the treatments with $\mathrm{ZnO}-\mathrm{NPs}$ at 6 and $18 \mathrm{mg} \mathrm{L}^{-1}$ increased the pigment content. The same trend was found regarding $\mathrm{Chl} b$, where the two highest dosages raised the pigment content compared to untreated controls. On the contrary, the dosage $2 \mathrm{mg} \mathrm{L}^{-1}$ was ineffective in affecting the content of these molecules. Furthermore, regarding the total chlorophyll, the treatment $\mathrm{ZnO}-\mathrm{NPs}$ at the concentrations 6 and $18 \mathrm{mg} \mathrm{L}^{-1}$ determined significant increases in this parameter, while the lowest ZnO-NPs concentration did not alter the total chlorophyll. Finally, all the ZnO-NPs treatments substantially stimulated the soluble protein content, with the highest effects found for 6 and $18 \mathrm{mg} \mathrm{L}^{-1}$, which, however, did not statistically differ from each other.

\subsection{Effects of ZnO-NPs on Carotenoids, Anthocyanins, Total Phenol Content (TPC) and Radical Scavenging Rate (DPPH)}

The effect on some other pigments, with, among other things, the antioxidant role in cells, the total phenol content and the radical scavenging activity were investigated in olive treated with the three concentrations of $\mathrm{ZnO}-\mathrm{NPs}$ and compared to untreated controls (Table 2).

Table 2. Carotenoids, anthocyanins, total phenol content (TPC), and radical scavenging rate (DPPH) found in olive proliferated explants.

\begin{tabular}{ccccc}
\hline & $\begin{array}{c}\text { Carotenoids } \\
\left.\mathbf{( m g ~ g ~}^{-1} \mathbf{F W}\right)\end{array}$ & $\begin{array}{c}\text { Anthocyanins } \\
\left.\mathbf{( m g ~ g}^{-1} \mathbf{F W}\right)\end{array}$ & $\begin{array}{c}\text { TPC } \\
\mathbf{( m g ~ g ~}^{-1} \text { FW GAE) }\end{array}$ & $\begin{array}{c}\text { DPPH } \\
\mathbf{( \% )}\end{array}$ \\
\hline Control & $3.23 \pm 0.59 \mathrm{bc}$ & $0.083 \pm 0.010 \mathrm{~b}$ & $2.11 \pm 0.10 \mathrm{~b}$ & $52.7 \pm 3.1 \mathrm{~b}$ \\
$2 \mathrm{mg} \mathrm{L}^{-1}$ & $2.70 \pm 0.73 \mathrm{c}$ & $0.099 \pm 0.014 \mathrm{ab}$ & $2.63 \pm 0.36 \mathrm{ab}$ & $49.7 \pm 3.6 \mathrm{~b}$ \\
$6 \mathrm{mg} \mathrm{L}^{-1}$ & $4.24 \pm 0.05 \mathrm{ab}$ & $0.098 \pm 0.110 \mathrm{ab}$ & $2.75 \pm 0.22 \mathrm{a}$ & $60.3 \pm 2.0 \mathrm{a}$ \\
$18 \mathrm{mg} \mathrm{L}^{-1}$ & $4.80 \pm 0.90 \mathrm{a}$ & $0.110 \pm 0.015 \mathrm{a}$ & $2.62 \pm 0.17 \mathrm{a}$ & $64.5 \pm 2.9 \mathrm{a}$ \\
\hline
\end{tabular}

Letters in the table, if different, indicate statistically significant differences $(p<0.05)$.

As for carotenoids, $\mathrm{ZnO}-\mathrm{NPs}$ at the concentration of $18 \mathrm{mg} \mathrm{L}^{-1}$ were able to significantly increase the content of these molecules, while the other dosages were found to be ineffective. A very similar trend to that exhibited by carotenoids was found by anthocyanins. In fact, the only dosage effective in elevating the content of this compound in the examined tissues was $\mathrm{ZnO}-\mathrm{NPs}$ at the dose of $18 \mathrm{mg} \mathrm{L}^{-1}$. 
Differently, the two highest ZnO-NPs dosages investigated were instead capable of elevating the TPC, resulting in significant increases compared to untreated controls, while even in this case, the $2 \mathrm{mg} \mathrm{L}^{-1}$ was found to be ineffective in affecting this parameter. Finally, the antioxidant activity, measured as radical scavenging rate towards DPPH, showed as the dosages effective in significantly increasing this protective function were ZnO-NPs at 6 and $18 \mathrm{mg} \mathrm{L}^{-1}$, whilst $2 \mathrm{mg} \mathrm{L}^{-1}$ was ineffective in influencing the antioxidant activity.

\section{Discussion}

In recent times, the interest in nanotechnology has been continuously increasing because of its vast application possibilities in different sectors, including the agricultural one. In particular, green synthesized ZnO-NPs show numerous advantages over those obtained from the traditional chemical synthetic procedures. Indeed, the green synthesis process does not impact the environment, and the obtained biogenic ZnO-NPs, thanks to their characteristics (morphology, shape, and size), can positively impact plant growth and productivity [7].

In this context, the effects of biogenic $\mathrm{ZnO}-\mathrm{NPs}$ obtained from Lemna minor L. on in vitro vegetative and biochemical parameters on olive tree cv. 'Moraiolo' were investigated. The results indicated that $\mathrm{ZnO}-\mathrm{NPs}$ added in the proliferation medium at the concentrations of 6 and $18 \mathrm{mg} \mathrm{L}^{-1}$ improved the number of shoots, the green fresh weight, and the total dry weight. $\mathrm{Zn}$ is involved in protein synthesis, carbohydrates, lipids, and nucleic acids metabolism [1]; therefore, its addition to the substrate for in vitro cultivation during the proliferation phase improved multiplication and explants growth.

The higher number of shoots observed in olive tree proliferated explants is of particular interest. Indeed, despite several studies carried out in order to improve the in vitro culture conditions for some olive cultivars, olive micropropagation rates are still in general limited [40]. In particular, the formation of secondary axillary shoots is very limited, usually due to the strong apical dominance, and uni-nodal explants with bilateral buds typically produce just one or, occasionally, two shoots and so shoot proliferation rate is generally low and cultivar dependent [41,42]. Consequently, olive shoot multiplication is mainly performed by segmentation of elongated shoots at each subculture. Similar results about the breaking of apical dominance were obtained by Garcia et al. using mannitol on their micropropagation trials with the 'Manzanillo' cultivar [43].

The observed increase in plant growth parameters in vitro due to the addition of $\mathrm{ZnO}-\mathrm{NPs}$ is in accordance with previous studies [16,44-46]. Javed et al. [44] investigated the effects of different concentrations $\left(0,0.1,1.0,10,100\right.$ or $\left.1000 \mathrm{mg} \mathrm{L}^{-1}\right)$ of $\mathrm{ZnO}-\mathrm{NPs}$ on growth parameters, steviol glycosides production, and antioxidant activities in the tissue culture grown shoots of Stevia rebaudiana Bertoni. At $1.0 \mathrm{mg} \mathrm{L}^{-1} \mathrm{ZnO}-\mathrm{NPs}$ positively influenced the shoots formation and steviol glycosides content, while adverse effects were observed at higher concentrations. In two pomegranate (Punica granatum L.) cultivars ('Manfalouty' and 'Wonderful'), growth in vitro conditions, ZnO-NPs added to the Woody Plant Medium (WPM) substrate determined an increase in the proliferation rate already at the concentration of $2.5 \mathrm{mg} \mathrm{L}^{-1}$. At the same time, $\mathrm{ZnO}-\mathrm{NPs}$ given at the concentration of $5 \mathrm{mg} \mathrm{L}^{-1}$ increased shoot length and biomass production [16]. In another work, the authors found that $\mathrm{ZnO}-\mathrm{NPs}$ at $10 \mathrm{mg} \mathrm{L}^{-1}$ promoted the differentiation of calli to shoots in Brassica nigra Koch while at higher concentrations, an increase in roots production and a decrease in shoots biomass was observed [45]. The nucellus tissues were inoculated on Murashige and Skoog (MS) medium with $30 \mu \mathrm{g} \mathrm{mL}{ }^{-1}$ suspension of zinc and copper nanoparticles. Green synthesized zinc and copper nanoparticles enhanced the in vitro germination parameters of Citrus reticulata Blanco [46].

Moreover, our study highlighted that the treatments with 6 and $18 \mathrm{mg} \mathrm{L}^{-1}$ of ZnO-NPs resulted in more robust olive explants. This aspect deserves attention, being very important for the transplanting phase under ex-vitro conditions since more vigorous plants develop more effective roots and show a greater adapting capacity to the ex-vitro conditions [29]. 
Improvements in the growth of explants of different olive cultivars were obtained by adding BAP, dikegulac, neem oil, or selenium to the growth media containing zeatin $[29,41,47,48]$ or coconut milk in combination with BAP without zeatin [40]. Therefore, our results show that in addition to the above-mentioned molecules, $\mathrm{ZnO}-\mathrm{NPs}$, at specific doses, can exert a positive effect on the growth of proliferated olive explants.

A multiplicity of factors can influence and modulate chlorophyll a and b, highlighting a close correlation between the content of these pivotal molecules and some abiotic inputs [49]. Nanomaterials, in general, and metal oxide nanoparticles, in particular, can influence the content of chlorophyll $a$ and $b$, both when plants are grown under normal conditions and abiotic stress, such as salinity and heavy metals exposure [50-52]. As for our study, significant increases in the content of $\mathrm{Chl} a$ and $b$ were found in samples exposed to the two highest ZnO-NPs dosages (Table 1). This effect can be explained based on the involvement of zinc in participating in chloroplasts formation and development and protochlorophyllide biosynthesis [7]. In particular, zinc is considered, among the nutrients, the most critical element that supports the biosynthesis of chlorophylls [53]. On this subject, some other studies have evidenced that also ZnO-NPs can be very effective in stimulating chlorophylls content in treated species. For instance, Salama et al. [53] found that ZnO-NPs increased in Phaseolus vulgaris the chlorophyll $\mathrm{a}$ and $\mathrm{b}$ content, concerning the dosage applied. In the cited work, such a beneficial effect was explained on the ability of ZnO-NPs to amplify the photosynthetic efficiency by increasing the chlorophyll capacity to absorb light. In particular, the mechanism undergoing this effect was the energy transfer from ZnO-NPs to chlorophyll a, which prompted, in turn, the increase in the pigment contents. In line with these findings, Mingyu et al. [54] found in spinach that nanoparticles can reach and affect the photosystem II (PSII), increasing its capacity to absorb light and accelerating the energy transferred from tyrosine to chlorophyll a. Finally, a study on the effect of ZnO-NPs, in combination or not with humic acids, was conducted on in vitro regeneration of palm [55]. The results demonstrated that chlorophyll $a$ and $b$, and total chlorophyll content were significantly increased by treating the plants with 50 and $75 \mathrm{mg} \mathrm{L}^{-1}$ of ZnO-NPs, while higher concentrations negatively impacted their amounts. The authors reported, among other things, that ZnO-NPs stimulated antioxidant defences and photosynthetic efficiency.

$\mathrm{ZnO}-\mathrm{NPs}$ can effectively stimulate some processes in plants, such as plant protein biosynthesis [56]. This effect, in turn, results in elevating biomass production and plant growth. Our experiments evidenced an increase in soluble protein content in the in vitro culture, regardless of the $\mathrm{ZnO}-\mathrm{NPs}$ dosage applied (Table 1). A recent and comprehensive study demonstrated that the treatment of tomato plants with ZnO-NPs induced the expression of genes involved in nutrient transport [17]. In addition, the authors also stated that NPs regulated carbon and nitrogen and the metabolism of some secondary metabolites. In line with these results, a study carried out using biogenic ZnO-NPs, obtained with Mentha arvensis L., evidenced as these NPs improved some biochemical and nutritional traits in Brassica napus L., also increasing the soluble protein content [57]. The authors stated that this effect resulted from the stimulatory action of zinc on nutrient acquisition and the induction of protein biosynthesis. Finally, soluble protein content increases were also found in Solanum nigrum callus treated with $\mathrm{ZnO}-\mathrm{NPs}$, and this effect was related to the protective action prompted by these NPs, and, in particular, to their capacity of stimulating antioxidant activities [58].

With regard to carotenoids, ZnO-NPs at the highest dosage increased the content of these molecules (Table 2). Carotenoids act as light-harvesting pigments, but, at the same time, they cover an essential protective antioxidant action for their ability in the removal of reactive oxygen species (ROS) [7,59]. In addition, carotenoids can quench chlorophyll in triplet and singlet form, preventing oxidative injuries to chloroplasts [7]. The increase of carotenoids recorded in our experiments is noteworthy as it supports the idea that the use of NPs can promote the growth and productivity of in vitro olive cultures, improving light-harvesting capacity and stress-resistance traits. Finally, the correlation between the content of chlorophyll and carotenoids is to be remarked. In fact, increases 
in the chlorophyll content, in response to proper stimuli like $\mathrm{ZnO}-\mathrm{NPs}$, can trigger the carotenoids biosynthesis as a protective feedback mechanism [60].

The other parameter investigated in this study was the anthocyanins content; these biomolecules derive from flavonoids and are localized in the vacuole [61]. Multiple functions are recognized to these compounds for their ability to act as antioxidants against ROS, inhibit the peroxidation of lipids, and protect plants from photo-inhibition due to light stress [62]. In addition, the involvement of anthocyanins in coping with the attacks of pathogens and insects has been documented [61]. However, in general, the content of anthocyanins increases with external stimuli, making the adaptability of plants to changes in environmental conditions easier [63]. The highest $\mathrm{ZnO}$-NPs dosage tested in our experiments increased the anthocyanins content in the in vitro olive culture (Table 2), while the other dosages did not. Nonetheless, the increase recorded at $18 \mathrm{mg} \mathrm{L}^{-1} \mathrm{ZnO}-\mathrm{NPs}$ can be seen as a protective mechanism activated by plants in response to ZnO-NPs, since these NPs can promote photo-oxidative processes due to the properties of their electrons of valence [64]. Accordingly, other studies showed that NPs could modulate anthocyanins content depending on the concentrations applied. In particular, the production of these molecules can increase at non-phytotoxic dosages, while excessive amounts of $\mathrm{ZnO}-\mathrm{NPs}$ can decline their content, as in the case of eggplant seedlings exposed to about $1000 \mathrm{mg} \mathrm{L}^{-1}$ of $\mathrm{ZnO}$-NPs [65]. In addition, a dose-response trend was recorded in tomato plants exposed to $\mathrm{ZnO}-\mathrm{NPs}$, where anthocyanin content raised in response to the highest dosages [66].

The total phenol content (TPC) was also investigated in our study since phenolics are considered essential antioxidants, like anthocyanins and carotenoids [67]. In particular, phenols act as oxygen radical scavengers for their electron reduction potential, which lower than those of oxygen radicals [68]. Also, phenol radicals produced during the phenols antioxidative activity are less reactive than other oxidants, allowing phenolic compounds to avoid continuing with further oxidative reactions [68]. Some studies evidenced increases in TPC following the treatments with ZnO-NPs, as in the case of Brassica nigra L. exposed to ZnO-NPs [69]. In a study carried out in micro-propagated Stevia rebaudiana, the authors found inductive effects on the total phenolics at moderate dosage (1.0 and $\left.10 \mathrm{mg} \mathrm{L}^{-1}\right)$, albeit higher dosages promptly declined the content of these compounds (100 and $1000 \mathrm{mg} \mathrm{L}^{-1}$ ) [44]. Finally, a very recent study investigated the effect of biogenic ZnO-NPs on Juniperus procera callus [68]. Again, the increase of total phenolics depended on the dosage applied, with the lowest being ineffective in modulating the content of these compounds, while the highest did prove to be effective [68]. The explanation of the increase in total phenols, as recorded in our study and the cited literature, lies in the role of phenols in coping with metal cations [68]. In fact, phenols also have the task of chelating metals in addition to their antioxidant function as ROS scavengers [68].

Finally, our experiments investigated the DPPH radical scavenging activity in olive cultures treated with ZnO-NPs (Table 2). DPPH is routinely evaluated to highlight antioxidant activity following abiotic and biotic stress exposure [44]. The results obtained for DPPH determinations were generally consistent with those observed in our experiments for carotenoids, anthocyanins and TPC. It is, therefore, reasonable to assume that the stimulatory effect of ZnO-NPs concerned the antioxidant activities due to the NPs ability to give rise to oxidative perturbations, which, however, at sub-toxic levels, promoted antioxidant defenses in treated plants. At last, our results are in line with other studies that shed light on the capacity of ZnO-NPs to elevate the DPPH radical scavenging activity and how this increase aligned with a general improvement of the antioxidant activities $[44,69]$.

Beneficial effects on plant growth and biochemical parameters were also observed with other NPs. For instance, engineered NPs-obtained doping with magnetic elements (Co and $\mathrm{Nd})$ iron oxide NPs $\left(\mathrm{CoNd}_{0.2} \mathrm{Fe}_{1.8} \mathrm{O}_{4}\right)$ were tested in barley [70]. These NPs showed beneficial effects in the treated crop by stimulating plant growth, relative water content, chlorophyll content, germination rate, and total fresh/dry weight. In addition, another study showed that $\gamma$ - $\mathrm{Fe}_{2} \mathrm{O}_{3}$-maghemite and $\mathrm{Fe}_{3} \mathrm{O}_{4}$-magnetite NPs improved in barley seed germination, plant growth, and biomass production [71]. However, some detrimental 
effects were observed in barley treated with $\alpha-\mathrm{Fe}_{2} \mathrm{O}_{3} \mathrm{NPs}$ that reduced the germination rate and pigmentation (chlorophyll-a, $-\mathrm{b}$, and carotenoids) [72].

\section{Conclusions}

In conclusion, this research revealed that the biogenic ZnO-NPs improved the number of shoots, the green fresh and the total dry weight. The higher number of shoots is significant for the olive micropropagation that usually is carried out only by segmentation of elongated shoots due to the limited formation of secondary axillary shoots for the strong apical dominance. In addition, the $\mathrm{ZnO}-\mathrm{NPs}$ showed beneficial effects on some biochemical traits of the treated olive crops, inducing the content of molecules involved in photosynthesis and plant growth. Furthermore, ZnO-NPs stimulated the total phenols and the radical scavenging activity in the olive samples. This action is to be remarked as the promotion of these factors can make the explants more resistant and adaptable for further uses.

Overall, the present study demonstrated for the first time the beneficial effects of using biogenic $\mathrm{ZnO}-\mathrm{NPs}$ on the in vitro proliferation of olive. This aspect deserves attention because of the absence of environmental impact correlated with the biogenic synthesis of nanostructured material, compared to classical techniques, and because of the implications of their effectiveness in improving the in vitro micropropagation techniques.

Finally, given the interest and potential application of the results obtained, further studies will be necessary to assess the medium and long term continuation of the beneficial effects promoted by NPs as well as the potential occurrence of toxic effects. The latter aspect is particularly relevant given the growing interest in nanotechnologies in agriculture.

Author Contributions: Conceptualization, L.R., D.D.B., M.M. and P.P.; Methodology, L.R., D.D.B. and M.M.; Investigation, L.R., D.D.B., M.M., S.L.F., C.T. and P.P.; Data curation, L.R., D.D.B., M.M., S.L.F., C.T. and P.P.; Writing-original draft preparation, L.R., D.D.B., M.M., S.L.F., C.T. and P.P.; Supervision, P.P. All authors have read and agreed to the published version of the manuscript.

Funding: This study was funded by the project "Ricerca di Base 2020" of the Department of Agricultural, Food and Environmental Sciences of the University of Perugia (Coordinator: Primo Proietti).

Institutional Review Board Statement: Not applicable.

Informed Consent Statement: Not applicable.

Data Availability Statement: The data that support the findings of this study are available from the corresponding author upon reasonable request.

Conflicts of Interest: The authors declare no conflict of interest.

\section{References}

1. Sturikova, H.; Krystofova, O.; Huska, D.; Adam, V. Zinc, Zinc Nanoparticles and Plants. J. Hazard. Mater. 2018, 349, 101-110. [CrossRef] [PubMed]

2. Palmer, C.M.; Guerinot, M.L. Facing the Challenges of Cu, Fe and Zn Homeostasis in Plants. Nat. Chem. Biol. 2009, 5, 333-340. [CrossRef] [PubMed]

3. Hänsch, R.; Mendel, R.R. Physiological Functions of Mineral Micronutrients (Cu, Zn, Mn, Fe, Ni, Mo, B, Cl). Physiol. Metab. 2009, 12, 259-266. [CrossRef] [PubMed]

4. Sharma, A.; Patni, B.; Shankhdhar, D.; Shankhdhar, S.C. Zinc-An Indispensable Micronutrient. Physiol. Mol. Biol. Plants 2013, 19, 11-20. [CrossRef]

5. Ren, F.-C.; Liu, T.-C.; Liu, H.-Q.; Hu, B.-Y. Influence of Zinc on the Growth, Distribution of Elements, and Metabolism of One-Year Old American Ginseng Plants. J. Plant Nutr. 1993, 16, 393-405. [CrossRef]

6. Del Buono, D.; Luzi, F.; Puglia, D. Lignin Nanoparticles: A Promising Tool to Improve Maize Physiological, Biochemical, and Chemical Traits. Nanomaterials 2021, 11, 846. [CrossRef]

7. Del Buono, D.; Di Michele, A.; Costantino, F.; Trevisan, M.; Lucini, L. Biogenic Zno Nanoparticles Synthesized Using a Novel Plant Extract: Application to Enhance Physiological and Biochemical Traits in Maize. Nanomaterials 2021, 11, 1270. [CrossRef]

8. Khot, L.R.; Sankaran, S.; Maja, J.M.; Ehsani, R.; Schuster, E.W. Applications of Nanomaterials in Agricultural Production and Crop Protection: A Review. Crop Prot. 2012, 35, 64-70. [CrossRef] 
9. Matussin, S.; Harunsani, M.H.; Tan, A.L.; Khan, M.M. Plant-Extract-Mediated $\mathrm{SnO}_{2}$ Nanoparticles: Synthesis and Applications. ACS Sustain. Chem. Eng. 2020, 8, 3040-3054. [CrossRef]

10. Nayantara; Kaur, P. Biosynthesis of Nanoparticles Using Eco-Friendly Factories and Their Role in Plant Pathogenicity: A Review. Biotechnol. Res. Innov. 2018, 2, 63-73. [CrossRef]

11. Karnan, T.; Selvakumar, S.A.S. Biosynthesis of ZnO Nanoparticles Using Rambutan (Nephelium Lappaceum, L.) Peel Extract and Their Photocatalytic Activity on Methyl Orange Dye. J. Mol. Struct. 2016, 1125, 358-365. [CrossRef]

12. Hessien, M.; Da'na, E.; Taha, A. Phytoextract Assisted Hydrothermal Synthesis of ZnO-NiO Nanocomposites Using Neem Leaves Extract. Ceram. Int. 2021, 47, 811-816. [CrossRef]

13. Jangannanavar, V.D.; Patil, M.K.; Chougala, L.S.; Inamdar, S.R.; Goudar, K.M. Biogenic Synthesis and Characterization of ZnO Nanoparticles from Aloe Barbadensis Miller Leaf Extract. Macromol. Symp. 2021, 400, 2100177. [CrossRef]

14. Vijayakumar, S.; Divya, M.; Vaseeharan, B.; Ranjan, S.; Kalaiselvi, V.; Dasgupta, N.; Chen, J.; Durán-Lara, E.F. Biogenic Preparation and Characterization of ZnO Nanoparticles from Natural Polysaccharide Azadirachta Indica.L. (Neem Gum) and Its Clinical Implications. J. Clust. Sci. 2021, 32, 983-993. [CrossRef]

15. Ahmed, S.; Annu; Chaudhry, S.A.; Ikram, S. A Review on Biogenic Synthesis of ZnO Nanoparticles Using Plant Extracts and Microbes: A Prospect towards Green Chemistry. J. Photochem. Photobiol. B 2017, 166, 272-284. [CrossRef]

16. El-Mahdy, M.T.; Elazab, D.S. Impact of Zinc Oxide Nanoparticles on Pomegranate Growth under In Vitro Conditions. Russ. J. Plant Physiol. 2020, 67, 162-167. [CrossRef]

17. Sun, L.; Wang, Y.; Wang, R.; Wang, R.; Zhang, P.; Ju, Q.; Xu, J. Physiological, Transcriptomic, and Metabolomic Analyses Reveal Zinc Oxide Nanoparticles Modulate Plant Growth in Tomato. Environ. Sci. Nano 2020, 7, 3587-3604. [CrossRef]

18. Pandey, A.C.; Sanjay, S.S.; Yadav, R.S. Application of ZnO Nanoparticles in Influencing the Growth Rate of Cicer Arietinum. J. Exp. Nanosci. 2010, 5, 488-497. [CrossRef]

19. Lin, D.; Xing, B. Root Uptake and Phytotoxicity of ZnO Nanoparticles. Environ. Sci. Technol. 2008, 42, 5580-5585. [CrossRef] [PubMed]

20. Prasad, T.N.V.K.V.; Sudhakar, P.; Sreenivasulu, Y.; Latha, P.; Munaswamy, V.; Raja Reddy, K.; Sreeprasad, T.S.; Sajanlal, P.R.; Pradeep, T. Effect of Nanoscale Zinc Oxide Particles on the Germination, Growth and Yield of Peanut. J. Plant Nutr. 2012, 35, 905-927. [CrossRef]

21. Sheoran, P.; Grewal, S.; Kumari, S.; Goel, S. Enhancement of Growth and Yield, Leaching Reduction in Triticum Aestivum Using Biogenic Synthesized Zinc Oxide Nanofertilizer. Biocatal. Agric. Biotechnol. 2021, 32, 101938. [CrossRef]

22. Ghosh, M.; Jana, A.; Sinha, S.; Jothiramajayam, M.; Nag, A.; Chakraborty, A.; Mukherjee, A.; Mukherjee, A. Effects of ZnO Nanoparticles in Plants: Cytotoxicity, Genotoxicity, Deregulation of Antioxidant Defenses, and Cell-Cycle Arrest. Mutat. Res.-Genet. Toxicol. Environ. Mutagen. 2016, 807, 25-32. [CrossRef] [PubMed]

23. Tripathi, D.K.; Mishra, R.K.; Singh, S.; Singh, S.; Vishwakarma, K.; Sharma, S.; Singh, V.P.; Singh, P.K.; Prasad, S.M.; Dubey, N.K.; et al. Nitric Oxide Ameliorates Zinc Oxide Nanoparticles Phytotoxicity in Wheat Seedlings: Implication of the AscorbateGlutathione Cycle. Front. Plant Sci. 2017, 8, 1. [CrossRef]

24. Kumar, V.; Parvatam, G.; Ravishankar, G.A. $\mathrm{AgNO}_{3}-\mathrm{A}$ Potential Regulator of Ethylene Activity and Plant Growth Modulator. Electron. J. Biotechnol. 2009, 12, 8-9. [CrossRef]

25. Aghdaei, M.; Salehi, H.; Sarmast, M.K. Effects of Silver Nanoparticles on Tecomella Undulata (Roxb.) Seem. Micropropagation. Adv. Hortic. Sci. 2012, 26, 21-24.

26. Wang, P.; Lombi, E.; Zhao, F.-J.; Kopittke, P.M. Nanotechnology: A New Opportunity in Plant Sciences. Trends Plant Sci. 2016, 21, 699-712. [CrossRef] [PubMed]

27. Spinoso-Castillo, J.L.; Chavez-Santoscoy, R.A.; Bogdanchikova, N.; Pérez-Sato, J.A.; Morales-Ramos, V.; Bello-Bello, J.J. Antimicrobial and Hormetic Effects of Silver Nanoparticles on in Vitro Regeneration of Vanilla (Vanilla Planifolia Jacks. Ex Andrews) Using a Temporary Immersion System. Plant Cell Tissue Organ Cult. PCTOC 2017, 129, 195-207. [CrossRef]

28. Asgari-Targhi, G.; Iranbakhsh, A.; Ardebili, Z.O. Potential Benefits and Phytotoxicity of Bulk and Nano-Chitosan on the Growth, Morphogenesis, Physiology, and Micropropagation of Capsicum Annuum. Plant Physiol. Biochem. 2018, 127, 393-402. [CrossRef]

29. Regni, L.; Micheli, M.; Del Pino, A.M.; Palmerini, C.A.; D'Amato, R.; Facchin, S.L.; Famiani, F.; Peruzzi, A.; Mairech, H.; Proietti, P. The First Evidence of the Beneficial Effects of Se-Supplementation on in Vitro Cultivated Olive Tree Explants. Plants 2021, 10, 1630. [CrossRef]

30. Balla, I.; Mansvelt, L. Micropropagation of Peach Rootstocks and Cultivars. Methods Mol. Biol. 2013, 11013, 148. [CrossRef]

31. Dobránszki, J.; Teixeira da Silva, J.A. Micropropagation of Apple-A Review. Biotechnol. Adv. 2010, 28, 462-488. [CrossRef]

32. Kavand, S.; Kermani, M.J.; Haghnazari, A.; Khosravi, P.; Azimi, M.R. Micropropagation and Medium-Term Conservation of Rosa Pulverulenta. Acta Sci.-Agron. 2011, 33, 297-301. [CrossRef]

33. Rugini, E. In Vitro Propagation of Some Olive (Olea Europaea Sativa L.) Cultivars with Different Root-Ability, and Medium Development Using Analytical Data from Developing Shoots and Embryos. Sci. Hortic. 1984, 24, 123-134. [CrossRef]

34. Venkatachalam, P.; Priyanka, N.; Manikandan, K.; Ganeshbabu, I.; Indiraarulselvi, P.; Geetha, N.; Muralikrishna, K.; Bhattacharya, R.C.; Tiwari, M.; Sharma, N.; et al. Enhanced Plant Growth Promoting Role of Phycomolecules Coated Zinc Oxide Nanoparticles with P Supplementation in Cotton (Gossypium Hirsutum L.). Eff. Nanomater. Plants 2017, 110, 118-127. [CrossRef]

35. Bradford, M.M. A Rapid and Sensitive Method for the Quantitation of Microgram Quantities of Protein Utilizing the Principle of Protein-Dye Binding. Anal. Biochem. 1976, 72, 248-254. [CrossRef] 
36. EL Arroussi, H.; Benhima, R.; Elbaouchi, A.; Sijilmassi, B.; EL Mernissi, N.; Aafsar, A.; Meftah-Kadmiri, I.; Bendaou, N.; Smouni, A. Dunaliella Salina Exopolysaccharides: A Promising Biostimulant for Salt Stress Tolerance in Tomato (Solanum Lycopersicum). J. Appl. Phycol. 2018, 30, 2929-2941. [CrossRef]

37. Paradiković, N.; Vinković, T.; Vinković Vrček, I.; Žuntar, I.; Bojić, M.; Medić-Šarić, M. Effect of Natural Biostimulants on Yield and Nutritional Quality: An Example of Sweet Yellow Pepper (Capsicum Annuum L.) Plants. J. Sci. Food Agric. 2011, 91, $2146-2152$. [CrossRef] [PubMed]

38. Sheikhalipour, M.; Esmaielpour, B.; Behnamian, M.; Gohari, G.; Giglou, M.T.; Vachova, P.; Rastogi, A.; Brestic, M.; Skalicky, M. Chitosan-Selenium Nanoparticle (Cs-Se Np) Foliar Spray Alleviates Salt Stress in Bitter Melon. Nanomaterials 2021, 11, 684. [CrossRef] [PubMed]

39. Lenth, R.V. Least-Squares Means: The R Package Lsmeans. J. Stat. Softw. 2016, 69, 1-33. [CrossRef]

40. Peixe, A.; Raposo, A.; Lourenço, R.; Cardoso, H.; Macedo, E. Coconut Water and BAP Successfully Replaced Zeatin in Olive (Olea Europaea L.) Micropropagation. Sci. Hortic. 2007, 113, 1-7. [CrossRef]

41. Micheli, M.; da Silva, D.F.; Farinelli, D.; Agate, G.; Pio, R.; Famiani, F. Neem Oil Used as a "Complex Mixture" to Improve in Vitro Shoot Proliferation in Olive. HortScience 2018, 53, 531-534. [CrossRef]

42. Lambardi, M.; Ozudogru, E.A.; Roncasaglia, R. In Vitro Propagation of Olive (Olea Europaea L.) by Nodal Segmentation of Elongated Shoots. In Protocols for Micropropagation of Selected Economically-Important Horticultural Plants; Lambardi, M., Ozudogru, E.A., Jain, S.M., Eds.; Humana Press: Totowa, NJ, USA, 2013; pp. 33-44. ISBN 978-1-62703-074-8. [CrossRef]

43. García, J.L.; Troncoso, J.; Sarmiento, R.; Troncoso, A. Influence of Carbon Source and Concentration on the in Vitro Development of Olive Zygotic Embryos and Explants Raised from Them. Plant Cell Tissue Organ Cult. 2002, 69, 95-100. [CrossRef]

44. Javed, R.; Usman, M.; Yücesan, B.; Zia, M.; Gürel, E. Effect of Zinc Oxide (ZnO) Nanoparticles on Physiology and Steviol Glycosides Production in Micropropagated Shoots of Stevia Rebaudiana Bertoni. Plant Physiol. Biochem. 2017, 110, 94-99. [CrossRef] [PubMed]

45. Zafar, H.; Ali, A.; Ali, J.S.; Haq, I.U.; Zia, M. Effect of ZnO Nanoparticles on Brassica Nigra Seedlings and Stem Explants: Growth Dynamics and Antioxidative Response. Front. Plant Sci. 2016, 7, 535. [CrossRef] [PubMed]

46. Hussain, M.; Raja, N.; Mashwani, Z.-R.; Iqbal, M.; Ejaz, M.; Yasmeen, F. In Vitro Germination and Biochemical Profiling of Citrus Reticulata in Response to Green Synthesized Zinc and Copper Nanoparticles. IET Nanobiotechnol. 2017, 11, 790-796. [CrossRef]

47. Ali, A.; Ahmad, T.; Abbasi, N.A.; Hafiz, I.A. Effect of Different Media and Growth Regulators on in Vitro Shoot Proliferation of Olive Cultivar "Moraiolo". Pak. J. Bot. 2009, 41, 783-795.

48. Mendoza-De Gyves, E.; Rosana Mira, F.; Ruiu, F.; Rugini, E. Stimulation of Node and Lateral Shoot Formation in Micropropagation of Olive (Olea Europaea L.) by Using Dikegulac. Plant Cell Tissue Organ Cult. 2008, 92, 233-238. [CrossRef]

49. Sonobe, R.; Yamashita, H.; Mihara, H.; Morita, A.; Ikka, T. Estimation of Leaf Chlorophyll a, b and Carotenoid Contents and Their Ratios Using Hyperspectral Reflectance. Remote Sens. 2020, 12, 3265. [CrossRef]

50. El-Saadony, M.T.; Desoky, E.-S.M.; Saad, A.M.; Eid, R.S.M.; Selem, E.; Elrys, A.S. Biological Silicon Nanoparticles Improve Phaseolus Vulgaris L. Yield and Minimize Its Contaminant Contents on a Heavy Metals-Contaminated Saline Soil. J. Environ. Sci. China 2021, 106, 1-14. [CrossRef]

51. Manzoor, N.; Ahmed, T.; Noman, M.; Shahid, M.; Nazir, M.M.; Ali, L.; Alnusaire, T.S.; Li, B.; Schulin, R.; Wang, G. Iron Oxide Nanoparticles Ameliorated the Cadmium and Salinity Stresses in Wheat Plants, Facilitating Photosynthetic Pigments and Restricting Cadmium Uptake. Sci. Total Environ. 2021, 769, 145221. [CrossRef]

52. Singh, P.; Arif, Y.; Siddiqui, H.; Sami, F.; Zaidi, R.; Azam, A.; Alam, P.; Hayat, S. Nanoparticles Enhances the Salinity Toxicity Tolerance in Linum Usitatissimum L. by Modulating the Antioxidative Enzymes, Photosynthetic Efficiency, Redox Status and Cellular Damage. Ecotoxicol. Environ. Saf. 2021, 213, 112020. [CrossRef]

53. Salama, D.M.; Osman, S.A.; Abd El-Aziz, M.E.; Abd Elwahed, M.S.A.; Shaaban, E.A. Effect of Zinc Oxide Nanoparticles on the Growth, Genomic DNA, Production and the Quality of Common Dry Bean (Phaseolus Vulgaris). Biocatal. Agric. Biotechnol. 2019, 18, 101083. [CrossRef]

54. Mingyu, S.; Xiao, W.; Chao, L.; Chunxiang, Q.; Xiaoqing, L.; Liang, C.; Hao, H.; Fashui, H. Promotion of Energy Transfer and Oxygen Evolution in Spinach Photosystem Ii by Nano-Anatase TiO2. Biol. Trace Elem. Res. 2007, 119, 183-192. [CrossRef] [PubMed]

55. Al-Mayahi, A.M.W. The Effect of Humic Acid (HA) and Zinc Oxide Nanoparticles (ZnO-NPS) on in Vitro Regeneration of Date Palm (Phoenix Dactylifera L.) Cv. Quntar. Plant Cell Tissue Organ Cult. PCTOC 2021, 145, 445-456. [CrossRef]

56. El-Badri, A.M.A.; Batool, M.; Mohamed, I.A.A.; Khatab, A.; Sherif, A.; Wang, Z.; Salah, A.; Nishawy, E.; Ayaad, M.; Kuai, J.; et al. Modulation of Salinity Impact on Early Seedling Stage via Nano-Priming Application of Zinc Oxide on Rapeseed (Brassica Napus L.). Plant Physiol. Biochem. 2021, 166, 376-392. [CrossRef]

57. Sohail; Kamran, K.; Kemmerling, B.; Shutaywi, M.; Mashwani, Z.U.R. Nano Zinc Elicited Biochemical Characterization, Nutritional Assessment, Antioxidant Enzymes and Fatty Acid Profiling of Rapeseed. PLoS ONE 2020, 15, e0241568. [CrossRef]

58. Abdel-Wahab, D.A.; Othman, N.A.R.M.; Hamada, A.M. Zinc Oxide Nanoparticles Induce Changes in the Antioxidant Systems and Macromolecules in the Solanum Nigrum Callus. Egypt. J. Bot. 2020, 60, 503-517. [CrossRef]

59. Tedeschini, E.; Proietti, P.; Timorato, V.; D’Amato, R.; Nasini, L.; Dei Buono, D.; Businelli, D.; Frenguelli, G. Selenium as Stressor and Antioxidant Affects Pollen Performance in Olea Europaea. Flora-Morphol. Distrib. Funct. Ecol. Plants 2015, $215,16-22$. [CrossRef] 
60. Bartucca, M.L.; Guiducci, M.; Falcinelli, B.; Del Buono, D.; Benincasa, P. Blue:Red LED Light Proportion Affects Vegetative Parameters, Pigment Content, and Oxidative Status of Einkorn (Triticum Monococcum L. Ssp. Monococcum) Wheatgrass. J. Agric. Food Chem. 2020, 68, 8757-8763. [CrossRef]

61. Peng, C.; Lin, Z.; Lin, G.; Chen, S. The Anti-Photooxidation of Anthocyanins-Rich Leaves of a Purple Rice Cultivar. Sci. China C Life Sci. 2006, 49, 543-551. [CrossRef]

62. Tsuda, T.; Shiga, K.; Ohshima, K.; Kawakishi, S.; Osawa, T. Inhibition of Lipid Peroxidation and the Active Oxygen Radical Scavenging Effect of Anthocyanin Pigments Isolated from Phaseolus Vulgaris L. Biochem. Pharmacol. 1996, 52, 1033-1039. [CrossRef]

63. Gould, K.S.; Kuhn, D.N.; Lee, D.W.; Oberbauer, S.F. Why Leaves Are Sometimes Red. Nature 1995, 378, 241-242. [CrossRef]

64. Bustos-Torres, K.A.; Vazquez-Rodriguez, S.; la Cruz, A.M.; Sepulveda-Guzman, S.; Benavides, R.; Lopez-Gonzalez, R.; TorresMartínez, L.M. Influence of the Morphology of ZnO Nanomaterials on Photooxidation of Polypropylene/ZnO Composites. Mater. Sci. Semicond. Process. 2017, 68, 217-225. [CrossRef]

65. Baskar, V.; Nayeem, S.; Kuppuraj, S.P.; Muthu, T.; Ramalingam, S. Assessment of the Effects of Metal Oxide Nanoparticles on the Growth, Physiology and Metabolic Responses in in Vitro Grown Eggplant (Solanum Melongena). 3 Biotech 2018, 8, 362. [CrossRef] [PubMed]

66. Raigond, P.; Raigond, B.; Kaundal, B.; Singh, B.; Joshi, A.; Dutt, S. Effect of Zinc Nanoparticles on Antioxidative System of Potato Plants. J. Environ. Biol. 2017, 38, 435-439. [CrossRef]

67. Dobrikova, A.G.; Apostolova, E.L.; Hanć, A.; Yotsova, E.; Borisova, P.; Sperdouli, I.; Adamakis, I.-D.S.; Moustakas, M. Cadmium Toxicity in Salvia Sclarea L.: An Integrative Response of Element Uptake, Oxidative Stress Markers, Leaf Structure and Photosynthesis. Ecotoxicol. Environ. Saf. 2021, 209, 111851. [CrossRef]

68. Salih, A.M.; Al-Qurainy, F.; Khan, S.; Tarroum, M.; Nadeem, M.; Shaikhaldein, H.O.; Gaafar, A.-R.Z.; Alfarraj, N.S. Biosynthesis of Zinc Oxide Nanoparticles Using Phoenix Dactylifera and Their Effect on Biomass and Phytochemical Compounds in Juniperus Procera. Sci. Rep. 2021, 11, 19136. [CrossRef]

69. Zafar, H.; Abbasi, B.H.; Zia, M. Physiological and Antioxidative Response of Brassica Nigra (L.) to ZnO Nanoparticles Grown in Culture Media and Soil. Toxicol. Environ. Chem. 2019, 101, 281-299. [CrossRef]

70. Tombuloglu, H.; Slimani, Y.; Tombuloglu, G.; Alshammari, T.; Almessiere, M.; Korkmaz, A.D.; Baykal, A.; Samia, A.C.S. Engineered Magnetic Nanoparticles Enhance Chlorophyll Content and Growth of Barley through the Induction of Photosystem Genes. Environ. Sci. Pollut. Res. 2020, 27, 34311-34321. [CrossRef]

71. Tombuloglu, H.; Albenayyan, N.; Slimani, Y.; Akhtar, S.; Tombuloglu, G.; Almessiere, M.; Baykal, A.; Ercan, I.; Sabit, H.; Manikandan, A. Fate and Impact of Maghemite $\left(\gamma-\mathrm{Fe}_{2} \mathrm{O}_{3}\right)$ and Magnetite $\left(\mathrm{Fe}_{3} \mathrm{O}_{4}\right)$ Nanoparticles in Barley (Hordeum Vulgare L.). Environ. Sci. Pollut. Res. 2022, 29, 4710-4721. [CrossRef]

72. Tombuloglu, H.; Slimani, Y.; AlShammari, T.M.; Bargouti, M.; Ozdemir, M.; Tombuloglu, G.; Akhtar, S.; Sabit, H.; Hakeem, K.R.; Almessiere, M.; et al. Uptake, Translocation, and Physiological Effects of Hematite $\left(\alpha-\mathrm{Fe}_{2} \mathrm{O}_{3}\right)$ Nanoparticles in Barley (Hordeum Vulgare L.). Environ. Pollut. 2020, 266, 115391. [CrossRef] [PubMed] 